\title{
Note on Translations, Romanization, AND STYlistic Conventions
}

Throughout the text, Japanese proper names appear in Japanese order: surname first followed by given name (e.g., Tōjō Hediki instead of Hediki Tōjō), except in cases of Westerners of Japanese origin. The same rule applies to Chinese and Korean proper names in the text, except in cases of Westerners of Chinese or Korean origin. The one exception to this rule is Syngman Rhee (Yi Sung-man), the founding president of the Republic of Korea. Rhee, who spent over thirty years in the United States before the liberation of Korea in 1945, rendered his name in Western order (given name followed by surname). To simplify locating works cited in the notes, however, the names of Japanese, Chinese, and Korean authors appear in Western order, with the surname last.

In keeping with the Japanese practice of referring to a deceased emperor according to his reign name and not his personal name, I use the term Emperor Shōwa instead of Emperor Hirohito (the name by which he is universally known in the West). The same rule applies to his predecessors: Emperor Taishō (instead of Emperor Yoshihito) and Emperor Meiji (instead of Emperor Mutsuhito). Macrons indicate long vowels in Japanese words and names, except in the case of well-known place names (e.g., Tokyo).

I employ the Pinyin transliteration of most Chinese proper names, places, and organizations (e.g., Mao Zedong, Zhou En Lai, and Beijing, instead of Mao Tse-Tung and Chou En-Lai, and Peking). However, for places, organizations, and persons associated with Nationalist China (1926-49) and the Republic of China on Taiwan (1949-present), I use the Wade-Giles system of transliteration (e.g., Chiang Kai-Shek and the Kuomintang instead of Jiang Jieshi and the Guomintang). The Taiwanese government uses Wade-Giles transliterations in official English language documents.

The given names of Russian and German officials appear in the original language or in the case of Russian, the approximate transliteration into Latin script (e.g., Heinrich instead of Henry or Mikhail instead of Michael). I make an exception in cases where the English translation of a Russian proper name is more common in the scholarly literature (e.g., Tsar Nicholas II instead of Tsar Nikolai II). With the exception of the Russian title tsar, the military ranks, government offices, royal and noble titles of all officials appear in English (e.g., the German emperor Wilhelm 
II instead of Kaiser Wilhelm II). Furthermore, the English translations of Germanic titles of nobility and rank precede the person's given and surnames in the text instead of coming between the given name and surname (e.g., Prince Bernhard von Bülow instead of Bernhard Fürst von Bülow or Bernhard Prince von Bülow or General Count Alfred von Schlieffen instead of General Alfred Graf von Schlieffen). Finally, in the case of British hereditary peers below the degree of duke or life peers (after 1958), the person's full title appears in the initial reference followed by the courtesy form in subsequent references (e.g., the marquess of Salisbury, the earl of Selbourne, and Viscount Haldane, then subsequently, Lord Salisbury, Lord Selbourne, and Lord Haldane). 


\section{BALANCING RISKS}


